\title{
Wieslaw STEC
}

\section{UNIA BRZESKA I JĘZYK}

W serii Linqua sacra, wydawanej przez Towarzystwo Naukowe Katolickiego Uniwersytetu Lubelskiego, ukazał się tom rozpraw poświęcony językowym konsekwencjom unii brzeskiej'. Zamieszċzone w nim prace stanowią w zasadniczym zrębie owoc konferencji naukowej, która odbyła się w Kazimierzu n. Wisłą w listopadzie 1996 roku w związku z czterechsetletnią rocznicą synodu unijnego. Jakkolwiek intencją wydawcy było skoncentrowanie uwagi na problematyce bezpośrednio lub pośrednio łączącej się $\mathbf{z}$ tym ważnym w dziejach Rzeczypospolitej wydarzeniem, to w książce znalazły się też studia wykraczające poza zakreślone ramy tematyczne i chronologiczne, podejmujące szeroko rozumiane zagadnienia języka sakralnego.

Unia brzeska, do dziś będąca przedmiotem skrajnie rozbieżnych ocen naukowych, jawi się jako złożone zjawisko cywilizacyjne, budzące zainteresowanie badaczy różnych dyscyplin. Jest przy tym znamienne, iż o ile polityczno-społeczno-religijne jej aspekty opracowane zostały w sposób zadowalający, o tyle największe zaległości do odrobienia mają historycy literatury i języka, a nade wszystko wydawcy. Znaczna część materiałów źródłowych pozostaje w rękopisach, bądź też w trudno dostępnych XVI i XVIIwiecznych przekazach, a nieliczne przedruki późniejsze ${ }^{2}$ nie spełniaja współczesnych norm edytorskich. Zauważalne zmiany w tym zakresie nastapiły w ostatnich, "rocznicowych" latach, przynosząc wymierne efekty naukowe w postaci opracowań i studiów o charakterze ogólnym³ szczegółowych rozpraw

1 Czterechsetlecie unii brzeskiej. Zagadnienia języka religijnego. Pod red. Z. Leszczyńskiego, Towarzystwo Naukowe Katolickiego Uniwersytetu Lubelskiego, Lublin 1998.

2 Chodzi tu o rosyjskie edycje prawosławnych (głównie), katolickich i unickich druków polemicznych zwiazzanych bezpośrednio $\mathrm{z}$ unia zamieszczanych $\mathrm{w}$ kolejnych tomach dwóch monumentalnych serii: Russkaja Istoriczeskaja Biblioteka oraz Archiv Jugozapadnoj Rossji. Spośród licznych prac z lat ostatnich wymienić należy: Ukrainske barokko ta evropejskij kontekst. Pod red. A. K. Fedoruka. Kijv 1991; Przemiany w Polsce, Rosji, na Ukrainie, Białorusi i Litwie (druga połowa XVII - pierwsza XVIII w.). Wrocław 1991; Polska - Ukraina. 1000 lat sąsiedztwa. T. 2, Przemyśl 1994; Unia brzeska: geneza, dzieje $i$ konsekwencje $w$ 
interpretacyjnych ${ }^{4}$, oraz wydań najważniejszych tekstów literackich ${ }^{5}$. W nurcie nowych odczytań naszej przeszłości mieści się również recenzowany tom, ocalający od zapomnienia dzieła i twórców, zarówno architektów, jak i przeciwników unii. W otwierającym go studium Bogdana Walczaka Językowe konsekwencje unii brzeskiej sformułowane zostały postulaty badawcze w zakresie ogólnych i szczegółowych poszukiwań historycznojęzykowych. Autor nie ograniczył się przy tym do opracowania kwestionariusza pytań i problemów (co samo $\mathrm{w}$ sobie jest rzeczą cenna), lecz $\mathrm{w}$ wielu przypadkach przedstawił interesujące propozycje ich rozstrzygnięcia. Tak np., dostrzegając lingwistyczne skutki oddziaływania unii w obrębie trzech języków: cerkiewnosłowiańskiego, ruskiego i polskiego, postawił ciekawa, choć wymagająca potwierdzeń materiałowych, tezę o szczególnej jej roli w podniesieniu prestiżu cerkiewszczyzny. Jako pierwszy zwrócił też uwagę na konieczność precyzyjnego wyodrębnienia oraz opisu i interpretacji w planie diachronicznym wpływów polskich w języku ruskim. Wyjątkowo jednak płodnym intelektualnie wydaje się być postulat uwzględnienia w większym niż do tej pory stopniu roli polemiki wyznaniowej jako czynnika sprawczego rozwoju polskiego języka literackiego (dodajmy i zachodnioruskiego). Nie ulega wątpliwości, że to właśnie ona (podobnie jak było to w przypadku reformacji) przyczyniła się do leksykalnego i frazeologicznego wzbogacenia polszczyzny oraz do wzrostu jej

kulturze narodów stowiańskich. Pod red. R. Łużnego, F. Ziejki i A. Kępińskiego, Kraków 1994; Barok III/2 (6) 1996; 400-lecie Únii Brzeskiej: tto polityczne, skutki spoteczne i kulturalne. Pod red. A. Zakrzewskiego i J. Fałowskiego, Częstochowa 1996.

4 Zob. m.in.: T. Chynczewska-Hennel, Z problematyki wptywów kultury polskiej na rosyjska w XI'II wieku, Odrodzenie i Reformacja w Polsce (XXXV') 1990; B. Dupuy, La dialoque Rutski Moghila en vue de l'union des Ruthenes (1624-1647). Istina 35, 1990; R. Lużny, Adama Hipacego Pocieja "Paranetica". Z nowych odczytań najdawniejszej ruskiej literatury religijnopolemicznej, w: Unia brzeska, op. cit; tenże: Melencjusz Smotrycki, Kasjan Sakowicz i inni: zjawisko kulturowego "proteizmu" w dobie polsko-ruskiego baroku, w: W kregu kultury ukrainskiej. Pod red. W. Pilata, Olsztyn 1995.

5 Najważniejsze z inicjatyw wydawniczych to: Collected Works of Maletij Smotryc' kyj, Harvard Library of Early Ukrainian Literatur, Text, vol. I. D. A. Frick, Cambridge Massachusettes 1987; Lev Krevza 's "Obrona jedności cerkiewnej" and Zaxarija Kopystens 'kyj's "Palinodija". With and Introduction by O. Pritsak and B. Struminsky, Cambridge Massachusettes 1987; Marcin Broniewski, Ekthesis abo krótkie zebranie spraw, które się działy na partykularnym. $t j$. pomiastnym synodzie w Brześciu Litewskim, Wyd. J. Byliński, J. Długosz. Wrocław 1995; Marcin Broniewski, Apokrisis abo odpowiedz na ksiàzki o synodzie brzeskim 1596, imieniem ludzi starożytnej religijnej greckiej przez Chrystophora Philaletha. Wyd. J. Byliński. J. Długosz, Wroctaw 1994. 
sprawności stylistycznej. Odpowiedź na pytanie w jakim stopniu przynieść mogą wyłącznie rozpoznania szczegółowe.

Nowy wymiar polemiki unijnej dostrzegła Maria Karpluk w studium $\mathrm{Ku}$ dalekiemu pojednaniu. Dysputa prawoslawno-katolicka metropolity Piotra Mohyty z ks. Kasjanem Sakowiczem. Analiza leksykalna użytej przez obu pisarzy terminologii teologicznej dowiodła nie tylko istnienia, zasadniczych różnic $\mathrm{w}$ poziomie ich kultury literackiej, ale - co ważniejsze - obecności $w$ myśleniu Mohyły idei porozumienia Kościołów i tożsamości wiary. Potwierdzone $\mathrm{i}$ uzupełnione zostały $\mathrm{w}$ ten sposób spostrzeżenia badaczy odwołujących się do innej, niż językowa, materii przekazów źródłowych.

Pośrednim następstwom synodu brzeskiego poświęcone zostały rozprawy Zenona Leszczyńskiego Religijne słownictwo i frazeologia w Kronice mohylowskiej z 1747 roku, Mariana Kucały Odbicie prześladowań unitów w języku pamiętników oraz Bożeny Matuszczyk Do swego Boga. Religijne frazeologie w unickich opowiadaniach S. Żeromskiego $i$ W. Reymonta. Dwa ostatnie - mimo odmienności materiału interpretacyjnego (literatura pamiętnikarsko-wspomnieniowa i proza narracyjna) - poprzez dokładny opis środków leksykalnych (Kucała) i frazeologicznych (Matuszczyk) zrekonstruowały rzeczywistą i literacką sytuację represji wobec grekokatolików i ich heroiczną walką o zachowanie wiary.

Natomiast Leszczyński przedmiotem rozważań uczyni leksykę uwzględniającą różne relacje religijno-wyznaniowe, która rozpatrzona została w 3 głównych zespołach semantycznych; tj. wiara, uporządkowanie świata i organizacja kultu. Wnikliwa jej obserwacja pozwoliła na sformułowanie tezy o obecności w Kronice dwóch genetycznie różnych nurtów: bizantyjsko-ruskiego i rzymskiego oraz uznania środków językowych za główny klucz do rozpoznania skutków unii brzeskiej. Spostrzeżenie to ma wartość nie tylko - jak się wydaje w odniesieniu do rozpatrywanego utworu, ale rozciąga się i na inne obszary piśmiennictwa, zarówno ruskiego jak i polskiego. Otwiera przy tym nowe perspektywy interpretacyjne przed historykami literatury $w$ zakresie stylistycznych oraz ideowych odczytań słownictwa aksjologicznego, stanowiącego istotny składnik poetyki tekstów zwłaszcza polemicznych.

Dokonania najwybitniejszego poety białoruskiego XVII wieku Szymona Potockiego scharakteryzowane zostały w dwóch studiach autorstwa Krystyny Szcześniak i Ludmiły A. Jankowskiej. Ocena leksyki, fonetyki i grafii Wierszyo 
Męce Pańskiej w cerkwi mówionych pozwoliła zarówno na potwierdzenie i uzupełnienie konstatacji Romana Łużnego o syntezie cech różnych języków literackich i właściwości dialektalnych zbioru, jak i na uściślenie dyskusyjnej dotąd kwestii jego chronologii. Natomiast podjęta przez badaczki próba odczytania emblematycznych znaczeń dzieła stworzyła możliwości ostatecznego wyjaśnienia problemu głównych źródeł poetyki Potockiego. Żałować jedynie należy, że ograniczyły się one do językowo-stylistycznych interpretacji, rezygnując $z$ uwzględnienia kontekstu estetyki baroku i siedemnastowiecznej emblematyki polskiej. W tej sytuacji podjęcie tych zagadnień jawi się jako jedno z najważniejszych zadań stających przed historykami literatury. Dodajmy, iż jego realizacja jest znacznie ułatwiona dzięki wzorcowej wręcz edycji Wierszy, przedrukowanych bezpośrednio $\mathrm{z}$ rękopisu Państwowego Archiwum Akt Dawnych w Moskwie i dołączonej w formie aneksu do omawianych rozpraw.

Także poezję, tyle że późniejszą, umieścił w centrum swoich rozważań Michał Łesiów w artykule Osobliwości językowe cerkiewnych pieśni ukraińskich do św. Józefata. Drobiazgowy opis wybranych elementów gramatycznych i stylistycznych sześciu anonimowych utworów wydanych w roku 1989 uwypuklił zarówno ich ukraińską formę językową, jak i wyraźny charakter patriotyczny. Umożliwiło to datowanie pieśni na czasy ksztaltowania się ukraińskiej świadomości i tożsamości narodowej oraz religijno-obrzędowej.

Do tekstu liturgicznego jako źródła językowego odwołał się z kolei Leszek Moszyński w rozprawie Cerkiewnosłowiańska tzw. Moskiewska Msza Maryjna jako odzwierciedlenie litewsko-bialorusko-polskich kontaktów kulturalnych $w X V$ wieku. Autor podjął polemikę z wydawcą i komentatorem Mszy F. V. Maresem w kwestii autorstwa i czasu powstania polskiego przekładu. Za jego twórcę uznał białoruskiego mnicha przybyłego do Krakowa z klasztoru ławryszewskiego, a datę ostateczną tłumaczenia uściślił na jesień 1421-1422 roku. Przekonywająco dowiódł także, iż utwór napisany został bliżej nieznaną odmianką języka starocerkiewnosłowiańskiego, a obecna w nim specyficzna terminologia obrzędowo-religijna była rezultatem - podobnie jak w przypadku języka kancelaryjnego Wielkiego Księstwa Litewskiego - wielorakich kontaktów kulturowych.

Relacje między językiem a kulturą na przykładzie konstruowania szczególnego typu argumentacji teologicznej w prawosławiu rozpatrzył Henryk Duda w studium Pisać ikonę. Przywołując liczne metaforyczne wypowiedzi 
literackie i artystyczne, w których zwrot ów funkcjonuje, autor prześledził pochodzenie czasownika "pisać" w różnych językach słowiańskich. Na tej podstawie doszedł do wniosku, iż ten rodzaj dowodzenia religijnego nie znajduje uzasadnienia $w$ językoznawstwie $\mathrm{i}$ jest typowym przykładem mitu etymologicznego.

Kwestie związane $\mathrm{z}$ obecnością polskich znaków onomastycznych $\mathrm{w}$ materialnej kulturze pogranicza jako wyrazu swoistego przejawu skutków przyjęcia unii podjął Władysław Makarski w artykule Elementy zachodniochrześcijańskie $w$ toponimii $i w$ nazwach obiektów sakralnych na kresach wschodnich. Wycinkowe ustalenia autora, wykazu jące łaciński rodowód rozpatrywanego nazewnictwa, uznać należy za istotny fragment badań nad przyszłym globalnym opracowaniem stratygraficznym problematyki onomastycznej kresów, obrazującej złożony charakter stosunków etnicznojęzykowych.

Lingwistyczne aspekty pisarstwa Jakuba Wujka omówione zostały w rozprawach Danuty Bieńkowskiej Ekwiwalenty lacińskich rzeczowników w przekładzie Psałterza J. Wujka oraz Joanny Sobczykowej O zrozumiałości języka liturgicznego.

Porównanie zasobu rzeczownikowego tłumaczenia polskiego i Wulgaty pozwoliło Bieńkowskiej określić dokładnie istotę, formy i źródła wariantywności oddawania przez Wujka słownictwa pierwowzoru. Co więcej, stało się dodatkowym argumentem za renesansowym wymiarem translacji, wyrażającym się w obecności kontekstowych odpowiedników leksyki oryginału, poprawności językowej oraz bogactwie synonimiki stylistycznej.

Punktem wyjścia rozważań J. Sobczykowej stała się natomiast interpretacja refleksji zawartej w komentarzu do Wujkowego przekładu Biblii, głosząca tezę o braku koherencji między zrozumiałością wypowiadanego tekstu modlitwy jako aktu komunikacji a jego strukturą. Odwołując się da świadomości językowo-kulturalnej XVI wieku, autorka odkryła przyczyny posługiwania się łaciną jako językiem liturgicznym Kościoła zachodniego i opisała wypełniane przez nią funkcje socjalizujące, solemnizacyjne, edukacyjne oraz fatyczne.

Recenzowany tom dopełniają studia Hanny Makuchowskiej $O$ języku modlitwy oraz Małgorzaty Nowak Uwspółcześnienie języka religijnego. Językowa analiza form przepowiadania wspólnotowego. 
Traktując modlitwę jako użytkowy gatunek językowy (a nie literacki), Makuchowska dostrzega w niej funkcjonalną całość, składającą się ze specyficznej ramy (inwokacja oraz formuła końcowa) i poszczególnych aktów wyrażonych typowym zasobem leksykalno-stylistycznym. Jednocześnie diachroniczna konfrontacja dziewiętnastowiecznego tekstu modlitewnego $\mathbf{z}$ inskrypcją z roku 1992 doprowadziła do interesującego wniosku o uproszczeniu zachowań etykietalnych, o większym stopniu intymności i bezpośredniości w kontakcie ze sferą sacrum.

Tendencję do egalitaryzacji języka religijnego zaobserwować można również we współczesnych formach przepowiadania kościelnego, właściwych dla posoborowych wspólnot chrześcijańskich. Uaktualnienie przekazu biblijnego dokonuje się tu - zdaniem M. Nowak - poprzez wykorzystanie polszczyzny potocznej i żargonu, rozluźnienie struktur gramatycznych i fonetycznych, formułowanie wypowiedzi w stylu średnim i niskim oraz nadanie jej charakteru swobodnej rozmowy, dzięki czemu zbliża się ona do pierwotnego znaczenia homilii.

Czterechsetlecie unii brzeskiej przynosi bogaty i różnorodny materiał analityczny oraz oryginalne propozycje interpretacyjne i metodologiczne. Jest znaczącym krokiem na trudnej drodze do pełnej i uwolnionej od ideologicznych nawarstwień wcześniejszych syntezy jednego $\mathrm{z}$ najważniejszych $\mathrm{w}$ dziejach Rzeczypospolitej i narodów ościennych wydarzeń cywilizacyjno-kulturowych. 